\title{
Pengaruh Pencahayaan terhadap Kandungan Pigmen Tetraselmis chuii sebagai Sumber Antioksidan Alami
}

\author{
Nada Kristiani Ginting, Sri Sedjati*, Endang Supriyantini, Ali Ridlo \\ Departemen Ilmu Kelautan, Fakultas Perikanan dan Ilmu Kelautan, Universitas Diponegoro \\ Kampus Tembalang, Semarang 50275 Telp/Fax. 024-7474698 \\ Email: sedjati69@gmail.com
}

\begin{abstract}
Abstrak
Tetraselmis chuii merupakan alga hijau yang mengandung senyawa bioaktif seperti pigmen klorofil dan karotenoid. Pigmen klorofil dapat menurunkan risiko terkena kanker dan berpotensi sebagai antioksidan. Salah satu faktor eksternal yang berpengaruh terhadap kandungan pigmen adalah cahaya. Penelitian ini bertujuan untuk mengetahui pengaruh warna pencahayaan terhadap biomassa, kandungan pigmen dan aktivitas antioksidan T. chuii. Rancangan penelitian yang digunakan adalah rancangan acak blok dengan tiga kali pengulangan. Perlakuan pencahayaan yang diberikan adalah putih, merah, dan biru. Perhitungan kepadatan dan pengukuran parameter kualitas air dilakukan setiap hari. Pemanenan dilakukan pada saat fase stasioner hari ke - 4. Kadar pigmen (klorofil a, b dan karotenoid) dilakukan secara spektrofotometri dan uji aktivitas antioksidan dilakukan dengan DPPH (1,1-difenil-2-pikrilhidrazil). Hasil penelitian menunjukkan bahwa kepadatan sel tertinggi terdapat pada perlakuan pencahayaan putih sebesar $95.800 \mathrm{sel} / \mathrm{ml}$. Kandungan pigmen klorofil a dan klorofil b total tertinggi terdapat pada pencahayaan merah $(48,28 \mathrm{dan} 40,86 \mu \mathrm{g} / \mathrm{ml})$, serta karotenoid total tertinggi terdapat pada pencahayaan biru $(6,70 \mu \mathrm{g} / \mathrm{ml})$. Perlakuan perbedaan pencahayaan memberikan pengaruh nyata $(\mathrm{P}<0,05)$ terhadap kandungan pigmen (klorofil a, dan $\mathrm{b})$. Aktivitas antioksidan ekstrak T. chuii semua perlakuan tergolong sangat lemah ( $\mathrm{IC}_{50}$ lebih dari $200 \mathrm{ppm}$ ).
\end{abstract}

Kata kunci: Tetraselmis chuii, klorofil, karotenoid, pigmen, antioksidan.

\section{Abstract \\ Effect of Lighting on Pigments Content Tetraselmis chuii Source of Natural Antioxidants}

Tetraselmis chuii is a green algae which is containing bioactive compounds such as chlorophyll and carotenoid pigments. Chlorophyll may reduce the risk of cancer and potentially as an antioxidant. This research aims to know the effect of light colour on biomass, pigment and antioxidant activity content of $T$. chuii. The research design used was a complete randomized design with three repetitions. The light treatments provided are white, red, and blue. Calculation of density and measurement of water quality parameters on daily basis. Harvesting is done during the stasionary phase at fourth day. Pigment levels (chlorophyll $a, b$ and carotenoids) were performed by spectrophotometer and an antioxidant activity test was performed by DPPH (1,1-diphenyl-2-picrilhidrazil). The results showed that different colour lighting treatments had an effect $(P<0.05)$ on pigment content (chlorophyll $a, b$, and carotenoid). The highest total chlorophyll content of $a$ and chlorophyll $b$ were found in the highest red light $(48.28$ and $40.86 \mu \mathrm{g} / \mathrm{ml})$ and the highest total carotenoids were in blue light $(6.70 \mu \mathrm{g} / \mathrm{ml})$. The highest cell desity in white lighting treatment is 95,800 cell/ml. Potential antioxidant activity of T. chuii extract for all treatments were very low (IC 50 more than $200 \mathrm{ppm}$ ).

Keywords: Tetraselmis chuii, chlorophyll, carotenoids, pigments, antioxidant

\section{PENDAHULUAN}

Tetraselmis chuii merupakan salah satu mikroalga laut yang memiliki beberapa kandungan pigmen antara lain klorofil dan karotenoid. Tetraselmis chuii memiliki prospek cerah di masa mendatang sebagai sumber pangan ataupun produk kesehatan karena kandungan gizinya yang tinggi. Menurut Arkronrat et al. (2006), T. chuii mengandung protein $25,70 \%$, lemak $9,40 \%$, dan karbohidrat $16,60 \%$. Dilaporkan pula oleh Sani et 
al. (2014), T. chuii mengandung protein $48,42 \%$, lemak $9,70 \%$, karbohidrat $12,10 \%$, dan total klorofil 3,65-19,20 mg/g. Menurut Mohamed dan Omar (2012), T. chuii mengandung klorofil a (0.73 $\mu \mathrm{g} / \mathrm{ml})$, lemak (29.51\%), karbohidrat (13.93\%).

Tetraselmis chuii memanfaatkan energi matahari dan $\mathrm{CO}_{2}$ untuk keperluan fotosintesis. Intensitas cahaya sangat menentukan pertumbuhan $T$. chuii khususnya biopigmen yang dihasilkan dari lama penyinaran dan panjang gelombang yang digunakan untuk fotosintesis, yang berguna untuk pembentukan senyawa karbon organik. Menurut Richmond (2004), selama proses fotosintesis klorofil akan menangkap warna cahaya yang spesifik yaitu sebagian besar pencahayaan biru $(450-475 \mathrm{~nm})$ dan merah $(630-675 \mathrm{~nm})$. Warna cahaya merah dan biru dapat meningkatkan pigmen klorofil dibandingkan cahaya putih.

Senyawa bioaktif yang dihasilkan T. chuii adalah pigmen klorofil dan karotenoid. Klorofil dapat digunakan sebagai pewarna pada bidang farmasi, dan digunakan pula untuk produk kesehatan. Mengkonsumsi klorofil dapat menurunkan risiko terkena kanker dan berpotensi sebagai antioksidan (Sani et al., 2014). T. chuii mempunyai aktivitas antioksidan berkisar antara 2,55-31,29 $\mathrm{mg} / \mathrm{ml}$ dan total klorofil berkisar antara 3,65-19,20 mg/g (Sani et al., 2014). Menurut Widowati et al. (2017) dan Maligan et al. (2015), aktivitas antioksidan $\left(\mathrm{IC}_{50}\right)$ T. Chuii adalah 71,36 ppm dan 28,45 ppm.

Antioksidan adalah zat yang dapat menunda, memperlambat dan mencegah terjadinya proses oksidasi karena menangkap elektron bebas. Antioksidan mampu menghambat terjadinya penyakit degeneratif dan menghambat peroksidasi lipid pada makanan. Antioksidan termasuk salah satu jenis bahan tambahan pangan yang dapat digunakan untuk melindungi komponen makanan seperti lemak dan minyak.

Penelitian ini bertujuan untuk mengetahui pengaruh pencahayaan berbeda terhadap pertumbuhan dan kandungan pigmen klorofil dan karotenoid $T$. chuii. Kandungan pigmen diduga berpengaruh terhadap bioaktivitas ekstrak $T$ chuii, maka dianalisis juga aktivitas antioksidannya.

\section{MATERI DAN METODE}

Materi yang digunakan dalam penelitian ini adalah stok murni mikroalga $T$. chuii yang diperoleh dari Laboratorium Balai Besar Pengembangan Budidaya Air Payau (BBPBAP) Jepara.

Kultur T. chuii dilakukan dengan menggunakan 9 akuarium berkapasitas 3 L sebagai wadah media air. Air laut dengan salinitas $30 \mathrm{ppt}$ sebanyak 1,5 L dimasukkan kedalam akuarium dan ditambahkan pupuk sebanyak $2 \mathrm{ml}(1 \mathrm{ml} / \mathrm{L}) \mathrm{ke}$ dalam masing-masing akuarium (Tabel 1). Dilakukan aerasi hingga homogen, kemudian tambahkan 0,5 L inokulan T. chuii.

Tabel 1. Komposisi Pupuk T. Chuii

\begin{tabular}{ccc}
\hline No & Nama & Komposisi $(\mathrm{mg} / \mathrm{L})$ \\
\hline 1 & Urea & $80-100$ \\
2 & TSP & $40-50$ \\
3 & EDTA & $3-5$ \\
4 & ZA & $20-25$ \\
5 & $\mathrm{FeCl}_{3}$ & $0,5-1$ \\
6 & Vit. $_{12}$ & 0,001 \\
\hline
\end{tabular}

\section{Ekstraksi T. chuii}

Sampel yang sudah kering diekstraksi secara maserasi berturut - turut menggunakan pelarut aseton dan metanol. Ekstraksi pertama dilakukan dengan menggunakan pelarut aseton dengan perbandingan 1 : 20 (1 gram : $20 \mathrm{ml}$ aseton), diamkan selama 24 jam. Selanjutnya disentrifugasi dengan kecepatan $3000 \mathrm{rpm}$ selama 15 menit, lalu disaring menggunakan kertas saring Whatmann No 1. Filtrat yang diperoleh dimasukkan kedalam vial dan ditutup dengan alumunium foil. Residunya direndam kembali menggunakan pelarut metanol selama 1 x 24 jam, kemudian disentrifugasi dengan kecepatan $3000 \mathrm{rpm}$ selama 15 menit, dan disaring menggunakan kertas saring Whatmann no. 1, Filtrat dimasukkan kedalam vial dan ditutup dengan alumunium foil. Filtrat yang diperoleh dari kedua pelarut tersebut diuji kadar pigmen menggunakan spektofotometer dan kromatografi lapis tipis, selanjutnya diukur aktivitas antioksidannya.

\section{Analisis Kadar Pigmen}

Analisis kadar pigmen dilakukan pada ekstrak pelarut aseton dan metanol dengan menggunakan spektrofotometer UV-Vis (Kurniawan et al., 2010). Pigmen total didapatkan dari penjumlahan hasil pigmen kedua ekstrak tersebut. Kadar pigmen metanol dihitung menurut Lichtentaler dan Lichtentaler (1983). Kadar pigmen aseton dihitung menurut Arnon (1949).

\section{Analisis Pigmen dengan KLT}

Identifikasi pigmen dalam ekstrak mikroalga dilakukan menggunakan Kromatografi Lapis Tipis (KLT) dengan silika gel sebagai fase diam dan fase geraknya adalah aseton : dietileter : heksana (2:3:6) (Kondororik et al., 2015). 


\section{Uji Aktivitas Antioksidan}

Uji aktivitas antioksidan dilakukan menggunakan metode spektrofotometri menurut Maligan et al. (2015) dengan modifikasi variasi konsentrasi yaitu 200, 400, 600, 800, dan 1000 ppm dan tiap konsentrasi tersebut diambil $1 \mathrm{ml}$ dan dimasukkan kedalam vial yang berisi $3 \mathrm{ml}$ DPPH (1,1-difenil-2-pikrilhidrazil) $\quad 0,1 \mathrm{mM}$, selanjutnya diiinkubasi selama 30 menit. Absorbansi diukur pada panjang gelombang $517 \mathrm{~nm}$.Persentase inhibisi dihitung dengan menggunakan rumus Rosahdi et al. (2015).

Data persentase inhibisi yang diperoleh selanjutnya dibuat grafik dengan memasukkan nilai konsentrasi pada sumbu $\mathrm{x}$ dan persentase inhibisi pada sumbu $\mathrm{y}$, sehingga diperoleh persamaan regresi linear $\mathrm{y}=\mathrm{bx}+\mathrm{a}$. Nilai $\mathrm{IC}_{50}$ dihitung dengan memasukkan nilai $\mathrm{y}=50$, sehingga dihasilkan nilai $\mathrm{x}$ sebagai konsentrasi.

\section{HASIL DAN PEMBAHASAN}

Hasil pengukuran kualitas air yang dilakukan selama penelitian masih dalam kisaran normal untuk kehidupan T.Chuii (Maligan et al., 2015), suhu berkisar $26-28^{\circ} \mathrm{C}$, salinitas $30 \mathrm{ppt}$, dan $\mathrm{pH} 7$. Berdasarkan hasil kultur T. Chuii diperoleh rata rata kepadatan sel yang semakin meningkat, dan kepadatan tertinggi dicapai pada hari ke - 4 . Kepadatan T. Chuii tertinggi terdapat pada warna cahaya putih yaitu $95.800 \mathrm{sel} / \mathrm{ml}$, kemudian warna biru $52.200 \mathrm{sel} / \mathrm{ml}$ dan terendah warna merah $45.000 \mathrm{sel} / \mathrm{ml}$ (Tabel 2).

Laju pertumbuhan yang paling tinggi terdapat pada penyinaran cahaya putih dibandingkan dengan warna biru dan merah (Gambar 1).

Energi cahaya yang dikumpulkan oleh pigmen fotosintesis dalam pencahayaan warna putih lebih banyak digunakan untuk melakukan proses fotosintesis (Kurniawan et al., 2014). Ketika energi dan oksigen tersedia, mikroalga akan memanfaatkannya untuk pembelahan sel sehingga

Tabel 2. Kepadatan T. Chuii pada Pencahayaan Berbeda

\begin{tabular}{cccc}
\hline \multirow{2}{*}{ Hari } & \multicolumn{3}{c}{ Kepadatan Sel (x 10 $\left.0^{4} \mathrm{sel} / \mathrm{ml}\right)$} \\
\cline { 2 - 4 } & Putih & Merah & Biru \\
\hline 1 & $5,69 \pm 0.49$ & $2,44 \pm 0.13$ & $3,44 \pm 1.03$ \\
2 & $6,11 \pm 0.56$ & $3,53 \pm 0.41$ & $3,92 \pm 1.04$ \\
3 & $8,95 \pm 0.26$ & $3,97 \pm 0.05$ & $4,75 \pm 0.72$ \\
4 & $9,58 \pm 0.51$ & $4,50 \pm 0.14$ & $5,22 \pm 0.41$ \\
\hline
\end{tabular}

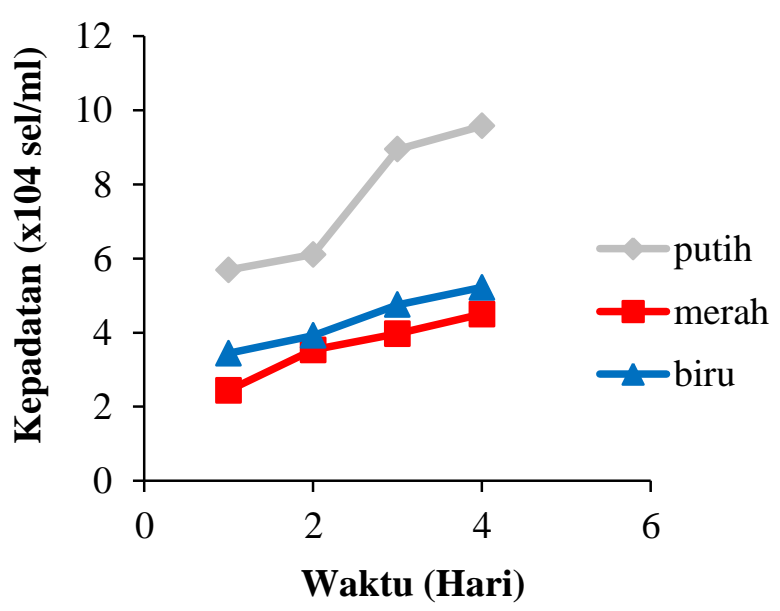

Gambar 1. Laju Pertumbuhan T. Chuii

kepadatan mikroalga akan bertambah karena pertumbuhan mikroalga akan terjadi secara cepat.

\section{Identifikasi Pigmen T. Chuii}

Analisis menggunakan spektrofotometer UVVis, pigmen klorofil a dari ekstrak metanol lebih besar dibandingkan dengan klorofil $b$ dan karotenoid. Pigmen klorofil a, dan klorofil b tertinggi terdapat pada pencahayaan merah yaitu $21,25 \mu \mathrm{g} / \mathrm{ml}$, dan $16,32 \mu \mathrm{g} / \mathrm{ml}$, kemudian pencahayaan biru yaitu $16,86 \mu \mathrm{g} / \mathrm{ml}$, dan 12,42 $\mu \mathrm{g} / \mathrm{ml}$ dan terendah pada pencahayaan putih yaitu $14,41 \mu \mathrm{g} / \mathrm{ml}, 10,35 \mu \mathrm{g} / \mathrm{ml}$. Sedangkan pigmen karotenoid pencahayaan biru lebih tinggi dibandingkan dengan pencahayaan merah dan putih (Tabel 3).

Kadar pigmen tertinggi pada ekstrak aseton klorofil a, klorofil b, dan karotenoid adalah pada pencahayaan putih yaitu 28,$21 ; 26,59$ dan 2,44 $\mu \mathrm{g} / \mathrm{ml}$, kemudian pencahayaan biru yaitu 28,08 ; 26,94 dan $1,95 \mu \mathrm{g} / \mathrm{ml}$ dan terendah pada pencahayaan merah yaitu 27,$03 ; 24,54$ dan 1,93 $\mu \mathrm{g} / \mathrm{ml}$ (Tabel 4).

Pelarut aseton menghasilkan kadar pigmen lebih tinggi karena pigmen yang bersifat non polar, yaitu : klorofil dan karotenoid lebih mudah larut dalam pelarut yang bersifat semi polar. Pigmen memiliki tingkat kelarutan yang rendah dalam pelarut metanol karena bersifat polar. Sehingga hasil serap pigmen dalam pelarut metanol lebih kecil dibandingkan dengan pelarut aseton.

Pigmen klorofil a dan $b$ total pada pencahayaan merah lebih tinggi dibandingkan dengan pencahayaan biru dan putih. Pigmen karotenoid total lebih tinggi pada pencahayaan biru dibandingkan dengan pencahayaan merah dan putih. Kadar pigmen klorofil a, klorofil b, dan karotenoid total pada pencahayaan merah yaitu 48,$28 ; 40,86$; 
dan $5,06 \mu \mathrm{g} / \mathrm{ml}$ pencahayaan biru yaitu 44,94; 39,36 dan $6,70 \mu \mathrm{g} / \mathrm{ml}$ dan pencahayaan putih yaitu 42,62 ; 36,95 dan 4,03 $\mu \mathrm{g} / \mathrm{ml}$ (Tabel 5)

Hasil uji Anova dan Tukey pada pigmen total, klorofil a dan klorofil $b$ menunjukkan bahwa pencahayaan putih berbeda nyata $(\mathrm{P}<0,05)$ dengan pencahayaan merah, sedangkan karotenoid menunjukkan bahwa pencahayaan putih tidak berbeda nyata $(\mathrm{P}>0,05)$ terhadap pencahayaan merah dan biru.

Kadar pigmen klorofil a dan klorofil b total $T$. chuii tertinggi ada pada pemberian pencahayaan merah kemudian biru dan putih karena pencahayaan merah memiliki panjang gelombang $630-675 \mathrm{~nm}$ lebih banyak diserap oleh pigmen klorofil. Menurut Campbell (2000) klorofil a dan klorofil b sangat baik menyerap spektrum merah. Klorofil b memiliki panjang gelombang sebesar $630-648 \mathrm{~nm}$ dan daya serap terhadap intensitas cahaya lebih pendek dibandingkan dengan klorofil-a yang memiliki panjang gelombang sebesar 660-682 nm tetapi mendekati cahaya merah sehingga kadar klorofil a dan klorofil $b$ total lebih tinggi.

Kadar karotenoid total yang tertinggi dicapai pada pemberian pencahayaan biru diikuti pencahayaan merah dan putih karena pada dasarnya pigmen karotenoid menyerap cahaya biru dengan panjang gelombang 450-475 nm (Kurniawan et al., 2013). Karotenoid bertindak sebagai pigmen permanen cahaya untuk menyerap energi di kisaran 400-500 nm yang tidak dapat diserap oleh klorofil (Kojo, 2004).
Identifikasi pigmen dilakukan menggunakan KLT (Kromotografi Lapis Tipis) dengan silica gel sebagai fase diam dan fase geraknya adalah aseton : dietileter : heksana (2:3:6). Hasilnya menunjukkan bahwa ekstrak metanol dan aseton mengandung 5 pigmen. Lapisan yang berada paling atas ataupun nilai $R_{f}$ yang paling tinggi adalah pigmen karotenoid yang berwarna orange, diikuti lapisan yang berwarna abu-abu merupakan pigmen feofitin a. Pigmen feofitin a sering ditemukan pada proses pemisahan klorofil melalui proses ekstraksi, selanjutnya lapisan yang berwarna hijau adalah pigmen klorofil yaitu hijau muda (hijau kebiruan) klorofil a dan hijau tua (hijau kekuningan) klorofil b. Lapisan yang berada dibawah ataupun nilai $R_{f}$ paling kecil adalah pigmen santofil dan berwarna kuning. (Tabel 6)

\section{Aktivitas Antioksidan T. Chuii}

Berdasarkan uji antioksidan ekstrak $T$. chuii diperoleh persamaan regresi linear sederhana yang ditunjukkan pada Gambar 2. Berdasarkan hasil tersebut, menunjukkan semakin tinggi konsentrasi ekstrak semakin tinggi nilai persen inhibisinya.Menurut Rosahdi et al. (2015) aktivitas antioksidan $\left(\mathrm{IC}_{50}\right) 50 \mathrm{ppm}$ tergolong kategori sangat kuat, 50-100 ppm kuat, 100-150 ppm sedang, 150200 ppm lemah dan > 200 ppm tergolong kategori sangat lemah. Aktivitas antioksidan ekstrak T. chuii yang didapatkan tergolong rendah karena $\left(\mathrm{IC}_{50}\right)>200 \mathrm{ppm}$ (Tabel 7).

Tabel 3. Kadar Pigmen T. Chuii dari ekstrak metanol.

\begin{tabular}{cccc}
\hline \multirow{2}{*}{ Perlakuan } & \multicolumn{3}{c}{ Kadar Pigmen $(\mu \mathrm{g} / \mathrm{ml})$} \\
\cline { 2 - 4 } & Klorofil a & Klorofil b & Karotenoid \\
\hline Putih & $14,41 \pm 2,01$ & $10,35 \pm 2,38$ & $1,59 \pm 0,52$ \\
Merah & $21,25 \pm 0,57$ & $16,32 \pm 1,20$ & $3,13 \pm 0,39$ \\
Biru & $16,86 \pm 2,54$ & $12,42 \pm 3,06$ & $4,75 \pm 0,66$ \\
\hline
\end{tabular}

Tabel 4. Kadar Pigmen T. Chuii dari ekstrak aseton.

\begin{tabular}{cccc}
\hline \multirow{2}{*}{ Perlakuan } & \multicolumn{3}{c}{ Kadar Pigmen $(\mu \mathrm{g} / \mathrm{ml})$} \\
\cline { 2 - 4 } & Klorofil a & Klorofil b & Karotenoid \\
\hline Putih & $28,21 \pm 0,29$ & $26,59 \pm 4,64$ & $2,44 \pm 0,13$ \\
Merah & $27,03 \pm 1,19$ & $24,54 \pm 2,56$ & $1,93 \pm 0,09$ \\
Biru & $28,08 \pm 0,89$ & $26,94 \pm 4,72$ & $1,95 \pm 0,24$ \\
\hline
\end{tabular}

Tabel 5. Kadar Pigmen total T. Chuii.

\begin{tabular}{cccc}
\hline \multirow{2}{*}{ Perlakuan } & \multicolumn{3}{c}{ Kadar Pigmen $(\mu \mathrm{g} / \mathrm{ml})$} \\
\cline { 2 - 4 } & Klorofil a & Klorofil b & Karotenoid \\
\hline Putih & $42,62 \pm 2,26$ & $36,95 \pm 2,02$ & $4,03 \pm 0,62$ \\
Merah & $48,28 \pm 1,71$ & $40,86 \pm 3,73$ & $5,06 \pm 0,29$ \\
Biru & $44,94 \pm 2,37$ & $39,36 \pm 5,85$ & $6,70 \pm 0,43$ \\
\hline
\end{tabular}


Tabel 6. Nilai $\mathrm{R}_{\mathrm{f}}$ Pigmen $T$. Chuii

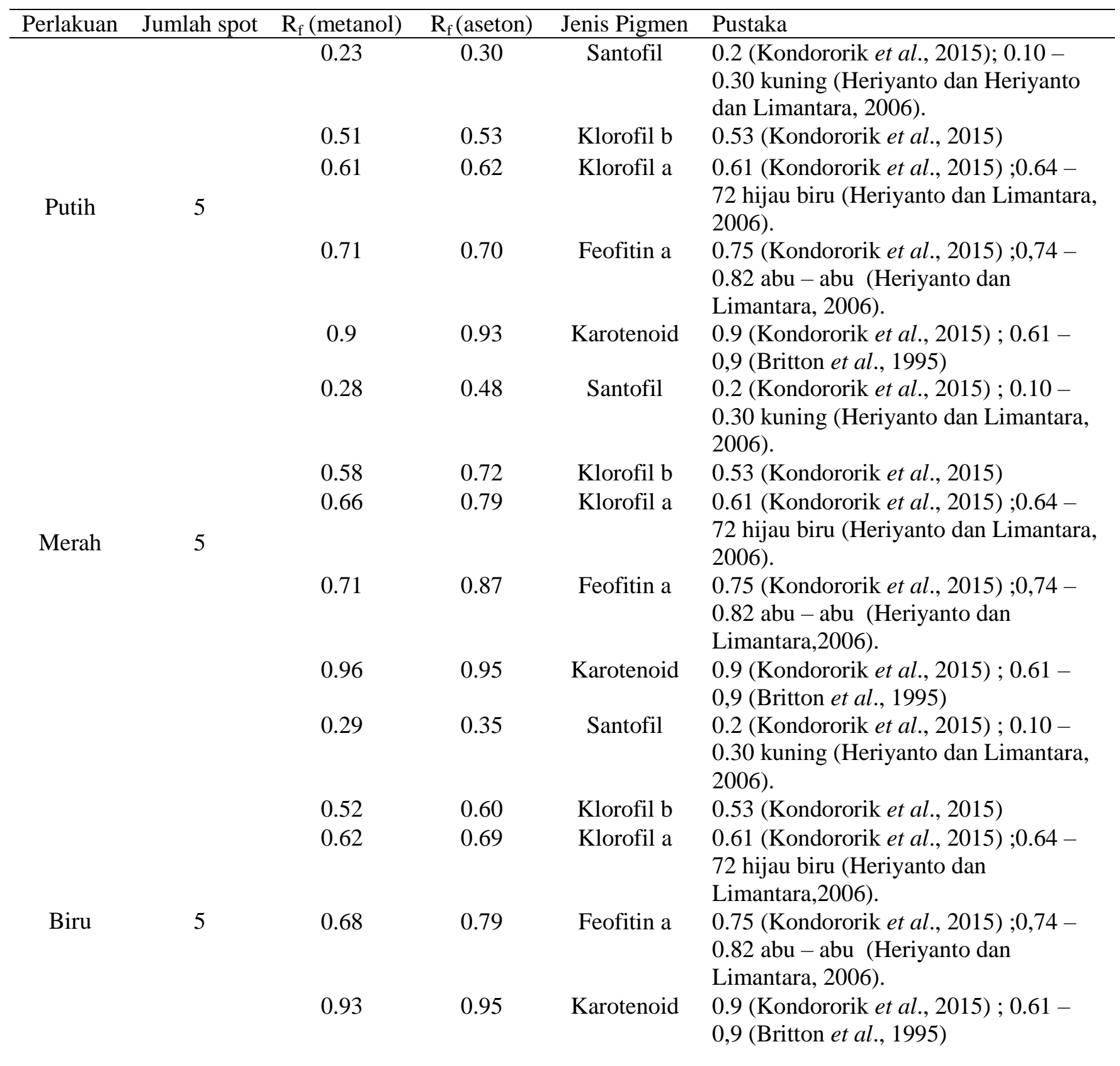

Tabel 7. Nilai $\mathrm{IC}_{50}$ Ekstrak T. chuii dengan Pencahayaan Berbeda

\begin{tabular}{ccrrr}
\hline \multirow{2}{*}{ No } & Konsentrasi (ppm) & \multicolumn{3}{c}{ \% Inhibisi } \\
\cline { 3 - 5 } & & $\mathrm{P}$ & \multicolumn{1}{c}{$\mathrm{M}$} & \multicolumn{1}{c}{$\mathrm{B}$} \\
\hline 1 & 200 & 21.28 & 18.09 & 14.89 \\
2 & 400 & 34.04 & 29.79 & 27.66 \\
3 & 600 & 40.43 & 38.72 & 34.04 \\
4 & 800 & 53.19 & 48.94 & 44.68 \\
5 & 1000 & 72.34 & 66.38 & 59.57 \\
\hline $\mathrm{IC}_{50}$ & & 695,176 & 765,811 & 859,862 \\
\hline
\end{tabular}




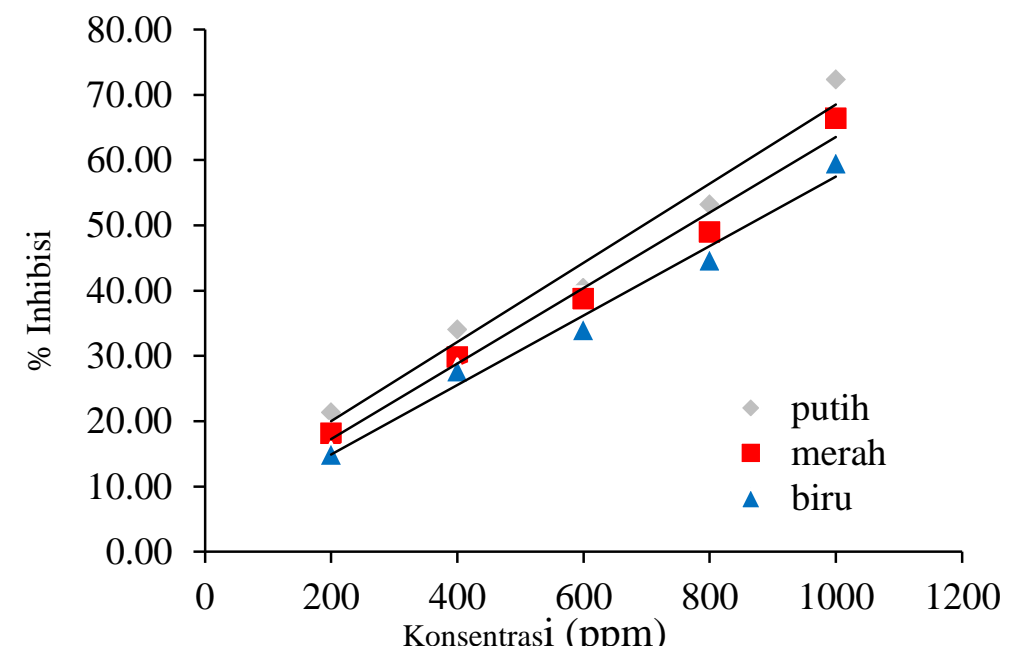

Gambar 2. Hubungan antara Konsentrasi Ekstrak dan \% Inhibisi

Aktivitas antioksidan dari ekstrak T. Chuii tergolong sangat lemah dapat disebabkan karena ekstrak yang diuji adalah ekstrak kasar yang senyawa antioksidannya belum murni. Ekstrak yang digunakan adalah dari serbuk kering. Proses pengeringan dapat mempengaruhi rusaknya senyawa antioksidan. Menurut Damar et al. (2014) sampel segar memiliki aktivitas antioksidan yang lebih baik karena memiliki tingkat kerusakan senyawa yang lebih kecil. Mikroalga $T$. chuii yang mengalami stress selama proses kultur juga dapat mempengaruhi hasil dari senyawa yang terkandung dan penyebab lemahnya aktivitas antioksidan (Yudiati et al., 2011)

\section{KESIMPULAN}

Berdasarkan hasil penelitian, dapat disimpulkan, bahwa pencahayaan yang berbeda tidak berpengaruh nyata $(\mathrm{P} \geq 0,05)$ terhadap laju pertumbuhan. Pencahayaan yang berbeda hanya berpengaruh nyata $(\mathrm{P}<0,05)$ terhadap kandungan pigmen total T. Chuii, yaitu : klorofil a, dan b, sementara terhadap karotenoid tidak berbeda nyata $(\mathrm{P} \geq 0,05)$. Pencahayaan putih dan merah menghasilkan kandungan klorofil $a$ dan $b$ berbeda nyata $(\mathrm{P}<0.05)$, tertinggi pada pencahayaan merah (klorofil a=48,28 $\mu \mathrm{g} / \mathrm{ml}, \mathrm{b}=40,86 \mu \mathrm{g} / \mathrm{ml}$ ). Aktivitas antioksidan ketiga ekstrak kering $T$. Chuii setelah pemberian pencahayaan berbeda (merah, putih, biru) tergolong sangat lemah $\left(\mathrm{IC}_{50}>200 \mathrm{ppm}\right)$.

\section{DAFTAR PUSTAKA}

Arkronrat, W., Deemark, P., \& Oniam, V. 2016. Growth Performance and Proximate Composition of Mixed Culture of Marine
Micoralgae (Nannochloropsis sp. \& Tetraselmis sp.) with monocultures. Songklanakarin J. Sci. Technol., 38(1):1-5

Arnon, D.I. 1949. Copper enzymes in isolated chloroplasts, polyphenol oxidase in Beta vulgaris. Plant Physiol., 2:1-15.

Campbell, N., B.R Jane, \& G.M Lawrence. 2000. Biologi. Erlangga, Jakarta.

Damar, A.R., Runtuwene, M.R.J., \& Silvia, D. 2014. Kandungan Flavonoid dan Aktivitas Antioksidan Total Ekstrak Etanol Daun Kayu Kapur (Melanolepsis multiglandulosa Reinch). Jurnal Ilmiah Farmasi. 3(4):11-21.

Heriyanto \& Limantara. 2006. Komposisi dan Kandungan Pigmen Utama Tumbuhan Taliputri Cuscuta australis R.Br. aan Cassytha filiformis L. Makara Sains, 10(2):69-75.

Kojo, S. 2004. Vitamin C: Basic Metabolism and Its Function as an Index of Oxidative Stress. Curr. Med. Chem. 11:1041-1064.

Kurniawan, M.P., Ma'ruf, W.F. and Agustini, T.W., 2014. Pengaruh Penambahan Mgco3 Dan Nahco3 Dengan Perbedaan Pencahayaan Terhadap Stabilitas Pigmen Klorofil-a Mikroalga Chlorella Vulgaris. J.Pengolahan dan Bioteknologi Hasil Perikanan, 3(2):25-33.

Kurniawan, M., Izzati, M. \& Nurchayati, Y. 2010. Kandungan Klorofil, Karotenoid, dan Vitamin $\mathrm{C}$ pada Beberapa Spesies Tumbuhan Akuatik. Buletin Anatomi dan Fisiologi, 18(1):1-14.

Kondororik, F., Martanto, M. \& Susanto, A.B. 2015. Identifikasi Komposisi Pigmen, Isolasi, dan Aktivitas Antioksidan $\beta$ Karoten pada Rumput Laut Merah Gracilaria gigas Hasil Budidaya. [Tesis]. Magister Biologi. Universitas Kristen Satya Wacana. 
Lichtentaler, H.K \& Wellburn, A.R. 1983. Determinations of Total Carotenoids and Chlorophylls a and b Leaf Extracts in Different Solvent. Biochem. Soc. Trans. 5:591-592

Maligan, J.M., Marditia, A.P. \& Putri, W.D.R 2015. Analisis Senyawa Bioaktif Ekstrak Mikroalga Laut Tetraselmis Chuii sebagai Sumber Antioksidan Alami. J. Rekapangan, 9(2):1-10.

Mohamed, A. \& Omar, M.W. 2012. Responses of Tetraselmis sp. And Nannochloropsis sp. Isolated from Penang National Park Coastal Waters, Malaysia, to the Combined Influences of Salinity, Light and Nitrogen Limitation. Int. Conf. Chem. Ecol. Environ. Sci.

Richmond, A. 2004. Handbook of Microalgal Culture : Biotechnology and Apllied Phycology. Blackwell Science.

Rosahdi T. D., Susanti, Y. \& Suhendar, D. 2015. Uji Aktivitas Daya Antioksidan Biopigmen
Pada Fraksi Aseton Dari Mikroalga Chlorella Vulgaris. J. Iistek 9 (1):1-14.

Sani, R.N., Nisa, F.C., Andriani \& Maligan, J.M. 2014. Analisis Rendemen dan Skrining Fitokimia Ekstrak Etanol Mikroalga Laut Tetraselmis chuii. Pangan dan Agroindustri. 2(2):121-126.

Widowati, I., M. Zainuri, H. P. Kusumaningrum, R. Susilowati, Y. Hardivillier, V. Leignel, N. Bourgougnon \& Jean-Luc Mouget. 2017. Antioxidant activity of three microalgae Dunaliella salina, Tetraselmis chuii and Isochrysis galbana clone Tahiti. IOP Conf. Ser.: Earth Environ. Sci. 55(012067): 1-6.

Yudiati, E., Sedjati, S., Sunarsih, \& Agustian, R. 2011. Aktivitas Antioksidan dan Toksisitas Ekstrak Metanol dan Pigmen Kasar Spirulina sp. Ind. J. Mar. Sci. 16(4):187-192. 